Marwah: Jurnal Perempuan, Agama dan Jender (p-ISSN: 1412-6095 | e-ISSN: 2407-1587)

Vol. 16, No. 2, 2017, Hal. $201-222$

\title{
ASAL MULA PENGKHIANATAN ISTRI DALAM PERSPEKTIF HADIS MISOGINI
}

\author{
Ridwan Hasbi \\ UIN Suska Riau, Indonesia \\ ongahridwan@yahoo.com
}

\begin{abstract}
The prophets Adam and Eve came out of heaven by eating the fruits that God forbade to eat, the event caused Eve to seduce her husband until she was deceived by the will of the wife. Then this incident made the origin of the form of betrayal of the wife to the husband who revealed the Prophet. The textual hadith's understanding is that Eve is identified as the traitor of the first family institution and this act becomes the identity of the traitorous woman of the husband throughout buman life. But this hadith should be understood contextually from the word "if not" is aimed at taubikh (ugly statement), traitor woman as majari sentence not to degrade woman dignity. The phrase of betrayal in the hadith is not the act of fahishah but merely violates God's probibition. In this context, Islam places women in an honorable position and has no hereditary sins. The assumption of misogyny in the badith is unfounded by the discovery of the hadiths of women's glory and marital relationship is the bond of the afterlife.
\end{abstract}

Keywords: Wife, Trait and Hadith

\begin{abstract}
ABSTRAK
Nabi Adam dan Hawa keluar dari surga dikarenakan memakan buah yang dilarang oleh Allah untuk dimakan, peristiwa itu disebabkan Hawa merayu suaminya sampai terpedaya mengikuti keinginan istri. Lalu kejadian ini dijadikan asal mula bentuk pengkhianatan istri terbadap suami yang diungkapkan Rasulullah. Pemahaman hadis secara tekstual adalah Hawa diidentikkan sebagai pengkhianat istitusi keluarga pertama dan perbuatannya ini menjadi identitas perempuan tukang pengkhianat suami sepanjang hidup manusia. Namun hadis ini harus dipahami secara kontekstual dari kata "seandainya bukan" adalah bertujuan untuk taubikh (pernyataan jelek), pengkhianat perempuan sebagai kalimat majazi bukan untuk merendahkan martabat perempuan. Ungkapan pengkhianatan dalam hadis bukan perbuatan fahishah tapi sebatas melanggar larangan Allah. Dalam konteks ini, Islam mendudukkan kaum perempuan pada posisi yang terbormat dan tidak ada namanya dosa turun temurun. Asumsi misogini dalam hadis tidak beralasan dengan mengemukan hadis-hadis kemulian perempuan dan bubungan suami istri adalah ikatan dunia akbirat.
\end{abstract}

Kata Kunci: Istri, Khianat dan Hadis 


\section{A. PENDAHULUAN}

Istri merupakan term pasangan dari suami dan suami adalah pasangan dari istri, lalu berkembang dengan sebuah istilah pasutri (pasangan suami istri). Suami istri implementasi dari penyatuan sepasang manusia dengan latar belakang yang sangat berbeda, baik dari sisi kebiasaan, budaya, cara hidup, pemikiran dan cita-cita. Prinsip awal dari penyatuan dua manusia yang berlainan jenis pada akad nikah yang merupakan ikatan lahir batin hidup bersama dalam satu institusi keluarga menuju sakinah, mawaddah dan rahmah.

Makna istri dalam bahasa Arab yaitu; pasangan dari laki-laki dengan dua term (Zaijah) dan زَوْجْ (Zam): bagi penduduk Najd, tanah Haram dan mayoritas bangsa Arab

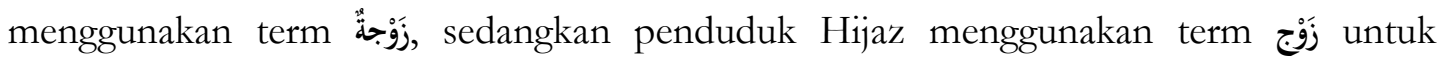
pasangan suami atau istri, namun Fuqaha menggunakan term زَوْجة sebagai pembeda antara perempuan dan laki-laki (al-Husainy). Dalam istilah Indonesia; istri adalah perempuan yang telah menikah atau yang bersuami (http://kbbi.web.id/istri.). Dalam Wikipedia bahasa Indonesia; kata istri berasal dari bahasa Sankerta yakni stri yang artinya "wanita" atau "perempuan" adalah salah seorang pelaku pernikahan yang berjenis kelamin wanita. Seorang wanita biasanya menikah dengan seorang pria dalam suatu upacara pernikahan sebelum diresmikan statusnya sebagai seorang istri dan pasangannya sebagai seorang suami (https://id.wikipedia.org/wiki/Istri).

Berdasarkan pengertian di atas seorang perempuan akan dinamai istri melalui proses pernikahan dengan seorang laki-laki. Ikatan lahir batin antara perempuan dan laki-laki dengan tujuan untuk membentuk institusi keluarga yang bahagia, kekal dan sejahtera. Ikatan akad pernikahan ini akan menghimpun dua kelompok besar, yakni keluarga suami dan keluarga istri sehingga hubungan mereka menyatukan dua keluarga besar menjadi satu. Posisi laki-laki sebagai suami menjadi sosok sentral dan istri sebagai sosok disamping suami mempunyai kewajiban yang sama berkorban untuk kepentingan bersama.

Paradigma sosok istri bukan sebagai pendamping sosok sentral saja tapi jauh dari itu sebagai penyokong dan bahkan sampai pada tahap tiang penyangggah. Islam memandang seorang istri sebagai sosok yang fundamental dalam sebuah institusi keluarga, sehingga keberadaannnya berkaitan dengan ketakwaan, amanah dan kalimat 
Allah yang terdapat dalam kandungan khutbah wada' Rasulullah SAW di Arafah, di antaranya;

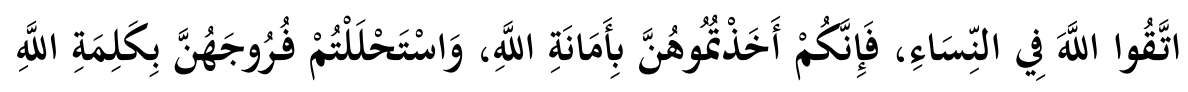

Bertakwalah kepada Allah dalam hal perempuan, sunggub kalian menjadikannya pasangan dengan amanah Allah dan kalian balalkan perempuan itu dengan kalimat Allah.

Konteks hadis di atas menjelaskan kepada kita bahwa seorang laki-laki harus mendudukkan posisi pertama dalam hidupnya adalah bertakwa terhadap kaum perempuan, ikatan esensial yang menjadikannya sebagai sosok istri adalah amanah Allah SWT dan kemudian landasan pondasi seorang perempuan menjadi pasangan hidupnya adalah kalimat Allah.

Mewujudkan itu bagi seorang Istri berdasarkan pada tugas dan fungsinya yang mencakup:

1. Seorang harus menyadari bahwa dirinya adalah bagian dari amanah yang diserahkan oleh Allah SWT pada suaminya

2. Seorang istri adalah pembina institusi keluarga yang sekaligus ibu rumah tangga yang bertanggung jawab atas harta benda milik suami dan pendidikan atas anak-anaknya

3. Seorang istri adalah penstabil dan penyelamat rumah tangga yang mampu menjadi sumber ketenangan bagi jiwa suami dan anak-anaknya

4. Seorang istri berusaha menjadi shalihah yang mengetahui kewajibannya terhadap Allah dan juga terhadap suaminya

5. Seorang istri berusaha menyenangkan bila dilihat suaminya, selalu menuruti kehendak suaminya selama tidak bertentangan dengan perintah Allah dan tidak menyelewengkan dirinya serta harta suaminya ke jalan yang tidak disukai suaminya (Dirjen Bimas Islam dan Penyelenggaran Haji , 2004).

Sebuah institusi keluarga, istri merupakan belahan jiwa suami sehingga wujud istri adalah wujud dari suami, perumpamaan al-Quran; istri adalah pakaian suami dan suami adalah pakaian istri merupakan ilustrasi dari korelasi antara pakaian dengan sang pemakai (Abu al-Thayib Muhammad Shadiq Khan ibn Hasn, 1992). Ilustrasi ini tercermin dalam lima fungsi keluarga, yaitu: afeksi, sosialisasi, reproduksi, ekonomi, dan perawatan keluarga.

Fungsi afeksi mencakup anggota keluarga akan saling memenuhi kebutuhan kasihsayang. Kemudian berkembang kepada fungsi sosialisasi yaitu: melalui keluarga 
seseorang akan menerima nilai-nilai dalam masyarakat. Orang tua akan mengajarkan melalui ucapan dan tindakan pada anak bagaimana berinteraksi dengan masyarakat serta mengajarkan nilai-nilai, norma budaya yang berlaku dimasyarakat untuk dipatuhi dijalankan secara baik dalam lingkungan sosial. Selanjutnya, suami istri memiliki kesempatan untuk menghasilkan keturunan melalui hubungan seks yang halal, inilah yang dinamakan dengan fungsi reproduksi. Dalam institusi keluarga segala kegiatan membutuhkan biaya, hal ini berkaitan dengan fungsi ekonomi, dimana keluarga berupaya memenuhi kebutuhan yang menyangkut makanan, pakaian, perabotan, perumahan dan lain sebagainya. Kemudian fungsi keluarga yang terakhir yaitu keperawatan, masing-masing anggota dalam keluarga akan berusaha saling melindungi, menjaga, memberikan rasa nyaman serta menerapkan hidup sehat dan bersih (Sri Sadewo, 2013).

Manifestasi fungsi "afeksi, sosialisasi, reproduksi, ekonomi, dan perawatan keluarga" dilandaskan pada ketakwaan, amanah dan kalimat Allah SWT. Landasan ini dikonotasikan dengan tugas dan fungsi istri secara umum berada pada ranah privat dan suami pada ranah publik. Ketika istri keluar dari ranah privat dengan mengacu pada emansipasi, kesetaraan gender dan bahkan dapat berkembaang dalam hak-hak asasi manusia sehingga berimplikasi pada permasalahan ekonomi, poltik, sosial dan hukum. Konteks manifestasi itu adalah institusi keluarga dalam Islam didasarkan pada pernikahan yang merupakan sebuah perjanjian yang tidak boleh dikhianati, dan bahkan pernikahan itu dikatakan sebuah perjanjian yang kuat dengan istilah mitsaqan ghaliza.

Dalam al-Quran terdapat satu perumpamaan tentang pengkhianatan seorang istri dalam institusi keluarga Nabi; Nuh dan Luth. Namun pengkhianatan ini bukan asal mula tapi dalam tataran contoh yang pernah terjadi di antara utusan Allah. Wujud pengkhianatan ini berkaitan dengan pasangan yang bersifat manusiawi tapi hal itu tidak boleh dilakukan, sebab konotasinya adalah sebuah perjanjian pernikahan.

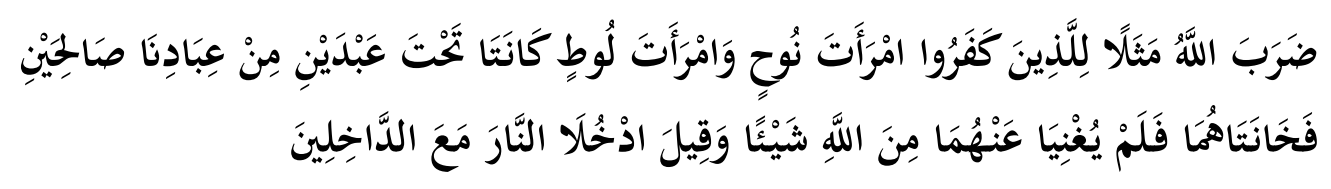

Allah membuat isteri Nuh dan isteri Luth sebagai perumpamaan bagi orang-orang kafir. Keduanya berada di bawah pengawasan dua orang hamba yang saleh di antara hamba-hamba Kami; lalu kedua isteri itu berkbianat kepada suaminya (masing-masing), maka suaminya itu tiada dapat membantu mereka sedikitpun dari (siksa) Allab; dan dikatakan (kepada keduanya): "Masuklab ke dalam jahannam bersama orang-orang yang masuk (jahannam) 
Pengkhianatan istri kedua Nabi ini berkaitan dengan persoalan agama bukan masalah perselingkuhan, atau menikahi mereka dalam kemusyrikatan. Ibnu Katsir menjelaskan bahwa pengkhianatan mereka berkaitan dengan keimanan yang tidak sempurna dan tidak menjalankan risalah (Abu al-Fida Ismail, 1993). Sisi yang lain menjelaskan bahwa pengkhianatan ini berkaitan dengan dakwah, bukan pengkhianatan dalam fahishah (perbuatan keji) dimana istri Nabi Nuh suka mengolok-ngolok bersama kaumnya tentang risalah Nabi Nuh. Sedangkan istri Nabi Luth memberi informasi tentang tamu-tamu Nabi Luth pada kaumnya padahal dia tahu keburukan mereka (Qutub, 1990).

Perumpamaan tentang pengkhianatan istri Nabi Nuh berkonotasi dengan suka menceritakan rahasia-rahasia Nabi Nuh kepada orang-orang yang tidak beriman kepada risalahnya, kemudian ikut dalam olokan itu, bahkan sampai mengatakan suaminya gila. Sedangkan perumpamaan yang kedua adalah istri Nabi Luth dengan pengkhianatannya berupa memberi tahu kepada orang-orang yang tidak beriman pada risalah Nabi luth berhubungan dengan tamu-tamu suaminya agar mereka bisa berbuat homoseksual dengan tamu-tamu tersebut (Ismail al-Haqy). Kedua perempuan ini telah mengkhianati amanat suami mereka dari sisi keharusan istri menjaga kehormatan dan memelihara rahasia suami serta tidak menyebarkan hal-hal yang orang lain tidak boleh tahu.

Konteks pengkhianatan ini dalam tataran hubungan suami istri yang keluar dari makna dan hakekat amanah, sehingga istri Nabi Nuh dan Luth AS dijadikan sebuah perumpamaan atas ketidak amanah mereka terhadap suami yang ma`shum. Term amanah dan khianat bertolakbelakang dalam implementasinya pada keberlangsungan sebuah institusi keluarga.

Perumpamaan atas istri Nabi Nuh dan Luth tidak dapat digeneralkan dalam semua aspek kehidupan institusi keluarga dengan memvonis bahwa perempuan adalah pengkhianat, tapi konteks yang sangat perlu ditela ah adalah kisah Nabi Adam dengan istrinya Hawa. Nabi Adam merupakan bapaknya manusia sedangkan Hawa sama kedudukannya dengan Adam sebagai manusia pertama yang diciptakan Allah. Konotasinya dalam hal pengkhianatan institusi keluarga adalah hadis Nabawi حَلَّ حَوَاءُ لَّمَ (Seandainya bukan karena Hawa, sunggub istri tidak akan pernab mengkhianati suami selamanya), korelasinya tentang realitas bahwa penyebab utama atas Nabi Adam keluar dari surga turun kepermukaan bumi adanya pengkhianatan istrinya Hawa. 
Sehingga Hawa menanggung celaan atas realitas pengkhianatan istri atas suami sepanjang kehidupan manusia di bumi.

Hadis itu menjadi sebuah fenomenal dengan menghubungkan asal mula pengkhianatan dalam institusi rumah tangga dengan menganggap kaum perempuan sebagai biang keladi terjadinya berbagai bentuk bencana dan tindak kriminalitas di dunia. Seperti negara hancur karena mereka, pertikaian muncul akibat perebutan perempuan. Bahkan sampai kepada sebuah vonis bahwa perempuan dianggap penyebab terjadinya dosa.

Wujud riil istri Nabi Adam yang dipresentasikan dalam hadis merupakan sebuah epistimologi misogini. Membongkar konteks hadis dengan mengacu kepada bahwa antara laki-laki dan perempuan kedudukan insaniyahnya sama dihadapan ajaran Islam, perempuan merupakan partner laki-laki dalam perjuangan sebab dibalik kesuksesan seorang laki-laki, tentu ada perempuan yang mendampinginya.

Dalam kontek yang lebih luas, kaum perempuan di tengah-tengah arus perubahan yang menggejala di berbagai belahan dunia yang pada prinsipnya menuntut kembali hakhak sebenarnya dari perempuan, maka umat Islam perlu meninjau dan mengkaji ulang anggapan-anggapan yang merendahkan martabat perempuan karena distorsi budaya, berdasarkan prinsip-prinsip kemuliaan Islam atas perempuan.

Salah satu implikasi yang tidak terelakkan adalah isu ini berusaha membongkar dogma-dogma agama, menentang sebagian ayat-ayat al-Qur'an, menghujat hadis-hadis dan melawan setiap ide penerapan hukum Islam dengan alasan ketidaklayakan hukum itu dalam membentengi hak-hak perempuan, bahkan jelas-jelas dianggap meminggirkan martabat perempuan sebagai makhluk yang diciptakan oleh Allah pendamping kaum laki-laki.

Perbedaan gender bukan merupakan suatu masalah yang serius manakala tidak menimbulkan berbagai persoalan seperti kesenjangan keadilan. Namun, pada kenyataannya adanya perbedaan gender acapkali menyebabkan adanya persoalan ketidakadilan baik di pihak laki-laki sendiri dan bahkan juga kebanyakan terjadi terhadap perempuan. Persoalan tersebut akan semakin rumit manakala terkait erat dengan doktrin ajaran agama. Islam sebagai agama yang Rahmatan Lil 'alamin meletakkan dasar-dasar yang ideal atas perempuan, sehingga persoalan "misoginis" dapat dibantah. 


\section{B. TINJAUAN PUSTAKA}

\section{Hadis Tentang Asal Mula Penghianatan Istri}

\section{Teks Hadis}

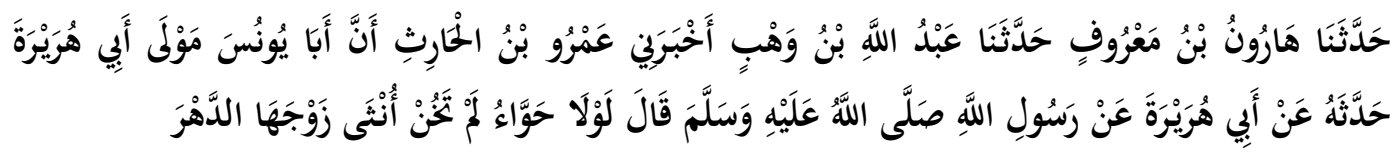

Artinya:

Telah meriwayatkan kepada kami Harun ibn Ma`ruf, juga Abdullab ibn Wahab, mengkabarkan kepada saya 'Amru ibn al-Harits bahwa bapak Yunus maula Abu Hurairah meriwayatkannya dari Abu Hurairah $\mathrm{R} A$; dari Rasulullah $S A W$ bersabda: "Seandainya bukan karena Hawa, sunggub istri tidak akan pernah mengkhianati suami selamanya".

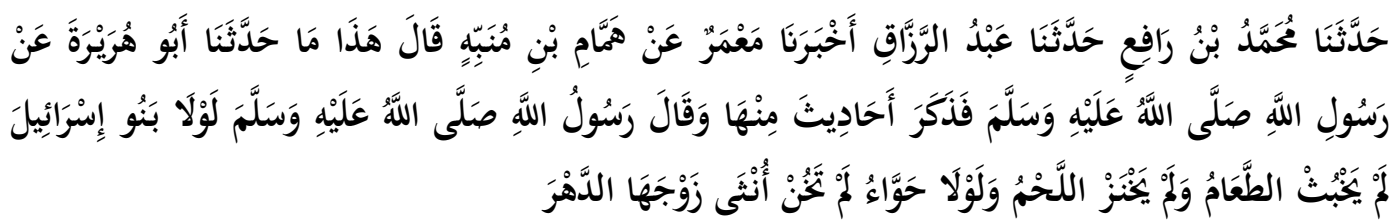

Artinya:

Telah meriwayatkan kepada kami Muahmmad ibn Rafi', juga Abdur Razaq, mengkabarkan pada kami Ma`mar dari Hammam ibn Munabbib berkata; ini yang diriwayatkan pada kami Abu Hurairah $\mathrm{R} A$, dari Rasulullah $S A W$ bahwasanya ia bersabda: "Seandainya bukan (karena) Bani Israil sungguh makanan tidak akan pernah rusak, daging tidak akan pernah busuk, dan seandainya bukan karena Hawa, sungguh istri tidak akan pernah mengkbianati suami selamanya".

\section{Kajian Sanad Hadis}

Dalam kitab al-Mujam al-Mufahras Lialfaz, al-Hadis al-Nabawi menyebutkan bahwa hadis ini terdapat pada riwayat al-Bukhari bab al-Anbiya 1 dan 25, Muslim pada Radha` 64 dan 65, serta Imam Ahmad ibn Hanbal 2, 304, 315 dan 349 (A.J Wensinck, 1943).

Hadits ini terdapat dalam kitab shahih al-Muslim dalam bab laula hawa lam takbun unsta zaujaha al-Dabr no. Hadits 1470, dalam shahih Muslim bi syarh alNawawi yang ditahqiqi oleh 'Isham al-Shababithy, Hazim Muhammad dan 'Imad 'Amir menyatakan mereka tidak mendapatkan hadits ini dari jamaah kecuali dalam shahih al-Muslim (al-Nawawi, 2001).

Syu ib al-Arnuuth dalam tahqiq hadis ini pada shahih Ibnu Hibban menyatakan bahwa hadis ini shahih dan para perawinya tsiqqat yang terdapat dalam jalur syaikhani (Bukhari Muslim). Terdapat dalam riwayat Ahmad 2/315 dari Abd Razaq, al-Bukhari mengeluarkan hadis ini no. 3399 pada hadis al-Anbiya` dari Abdullah ibn Muhammad al-Ja `y, Muslim pada 63 dan 1470 dalam al-Radha` bab Laula Hawa Lam Takbun Unts 
Zaujaha al-Dahr, dari Muhammad ibn Rafi, dan al-Bagwi no. 2335 dari Ahmad ibn Yusuf al-Sulamy dengan ketiganya dari Abd Razaq. Disamping itu Bukhari meriwayatkan no. 3330 dalam hadis al-Anbiya` bab Khalqu Adam wa Zurriyatibi dari Basyar ibn Muhammad dari Abdullah dari Ma mar. Muslim juga meriwayatkan dari Harun ibn Ma`ruf dari Abdullah ibn Wahab dari `Amru ibn al-Harits dari Abu Yunus Maula Abu Hurairah dari Abu Hurairah. Periwayatan Imam Ahmad dari Muhammad ibn Ja ‘ar dari `Auf dari Khilas ibn `Amru al-Hijry dari Abu Hurairah. Sedangkan alHakim meriwayatkan 4/175 dari jalur Ruh ibn `Ubadah dari `Aun dari Muhammad dari Abu Hurairah (Muhammad ibn Hibban ibn Ahmad ibn Hibban ibn Mu`az, 1988).

\section{Kajian Matan Hadis}

Hadis yang penulis temukan dalam permasalahan asal mula pengkhinatan sang istri terdapat dua periwayatan dengan matan hadis yang langsung pada persoalan pengkhianatan dan matan kedua didahului dengan asal mula makanan dan daging dapat rusak adalah Bani Israil. Dalam hal ini, penulis hanya memfokuskan pada mata

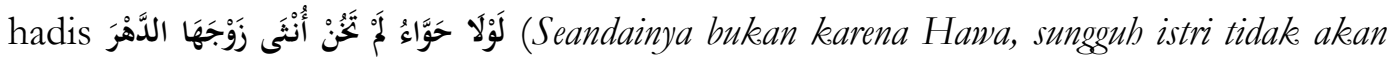
pernah mengkhianati suami selamanya).

Konstruksi perkataan Rasulullah SAW pada intinya terdapat dalam kalimat

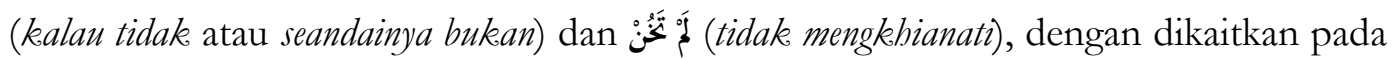
nenek manusia pertama Hawa yang membujuk Nabi Adam memakan buah pohon yang dilarang oleh Allah SWT, sehingga diturunkan dari surga. Kemudian perbuatan Hawa terhadap Nabi Adam diformulasi pada tataran "semua peristiwa pengkhianatan istri

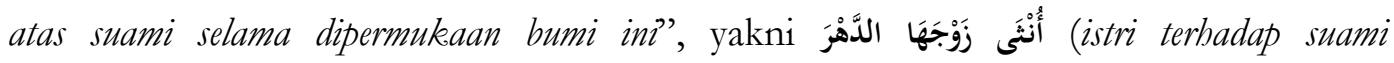
selamanya).

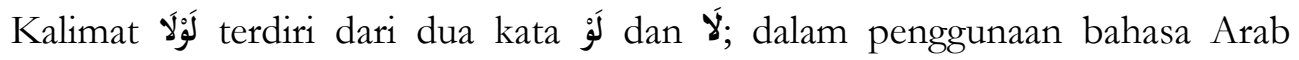
terdapat beberapa maksud, Ibnu Batthal mengatakan لَّ لَّ dikalangan orang Arab adalah larangan dengannya sesuatu sebab ada selainnya, al-Ragib mengatakan adalah karena terjadi selainnya, dan Ibnu Hisyam mengatakan bahwa لَّ mengandung maksud dalam salah satu tiga aspek (1) untuk mengikat larangan hal kedua sebab adanya hal pertama, (2) untuk mengajak dalam hal meminta, mencari dan untuk 
memohon dengan kelembutan dan beretika, (3) dalam للتوبيخ (untuk pernyataan buruk) dan التندم (untuk, pernyataan sesal) (Abu al-Fadhl Ahmad ibn Ali ibn Muhammad ibn

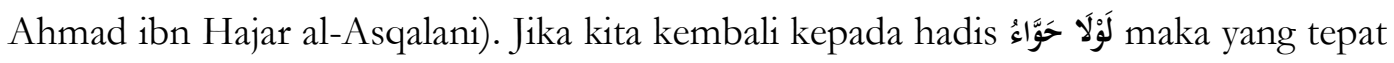
maksud dari aَ adalah untuk taubikh (pernyataan buruk) atas perbuatan dari Hawa. Dalam konteks larangan Rasulullah SAW menggunakan kata لَ sebab akan membuka pintu setan dalam merusak iman pada qadha dan qadar, sedangkan ungkapan dengan kalimat لَوَلَا dibolehkan karena berkaitan dengan suatu peristiwa yang telah terjadi (Abu al-'Abbas ibn Ahmad ibn Ibrahim). Seandainya bukan karena Hawa berkonotasi pada suatu peristiwa yang sudah terjadi dan berdampak pada kehidupan kaum perempuan sesudahnya.

Kata حَوَاءُ dengan huruf ha dan waw-nya bertasydid, merupakan term tentang istri Nabi Adam dan riwayat Ibnu Abbas mengatakan bahwa Hawa adalah ibu setiap manusia yang melahirkan 40 anak dalam 20 kali hamil dengan setiap persalinan kembar laki-laki dan perempuan (Abu Zakaria Yahya ibn Syarf al-Nawawi, 1392). Hawa diciptakan sebagai pendamping Nabi Adam dengan tujuan untuk melengkapi kebahagiaannya di surga. Dinamakan Hawa sebab ia diciptakan Allah dari حي(sesuatu yang bidup), disebut juga karena warna bibir Hawa berwarna kecoklat-coklatan, begitu juga pada dagunya terdapat tanda lahir berwarna kecoklat-coklatan. Ada juga yang mengatakan dinamakan Hawa sebab warna kulitnya dekat ke warna coklat, lebih dekat ke hitam begitupun dengan warna kulit Adam. Di samping itu dikatakan Hawa dari kata hawiyah yang berarti berlindung, dia hidup sesudah wafat Nabi Adam 9 tahun 9 bulan dengan umurnya sekitar 900-an tahun (Ismail al-Haqy ibn Mushtafa alIstanbuly).

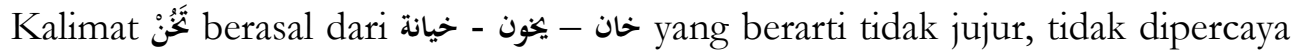
dan biasa disebut dengan khianat. Khianat merupakan lawan dari amanah; jika seseorang dikatakan mengkhianati janji berarti ia tidak melaksanakannya dan identik dengan tidak amanah (Ibrahim Mushthafa). Aplikasi khianat dalan hadis bahwa Hawa mengajak Nabi Adam untuk makan buah yang dilarang oleh Allah dengan merayu dan memperdaya sampai mau melanggar larangan Allah. Sehingga maksud dari khianat dalam hadis ini adalah ترك النَِّيحِة لَهُ فِ الْأكل من الشَّجرَة لَا فِي غَيرها (meninggaalkan 
nasehat untuknya dalam makan dari buah pohon, bukan pada masalah lain) (Abu al-Thaib Muhammad Shadiq Khan, 1981). Konteks khianat merupakan implementasi dari Nabi Adam yang terpedaya atas rayuan istrinya sehingga berani melanggar aturan Allah dengan mengikuti nafsu memakan buah yang dilarang bukan maksud dari khianat disini perselingkuhan atau melakukan perbuatan keji.

الزَّمانُ الطويُُ والأَمَدُ الدَّْرَ merupakan masa, zaman dan waktu yang lama yakni المَمْدُودُ (waktu yang panjang dan masa yang tidak terbatas) (Muhammad ibn Ya 'qub alFairuzabadi), sedangkan konotasinya penunjuk rentang masa selama-lamanya dan bersifat waktu yang batas akhirnya adalah kehidupan dunia. Ibnu Manzhur mengatakan bahwa الدَّهَ adalah masa yang tak berbatas dan selalu disebut dengan ribuan tahun, sifat yang dijadikan landasannya lebih dari satu masa dengan korelasi waktu yang lama (Ibnu Manzhur). Konteks masa yang tidak punya batas ini dalam pengkhianatan Hawa adalah sepanjang hidup manusia yang berkaitan dengan pengkhianatan istri terhadap suami bermula dari sang ibunda pertama. Konotasi dalam wujud perjalanan kehidupan bahwa pengkhianatan istri terhadap suami tidak pernah ada selamanya, jika istri Nabi Adam tidak berkhianat.

Konteks hadis tentang asal mula pengkhianatan dalam sebuah institusi keluarga yang disandarkan pada perbuatan Hawa istri dari Nabi Adam, dimana mereka dihadapkan pada satu aturan yang tidak boleh memakan buah dari satu pohon dalam surga.

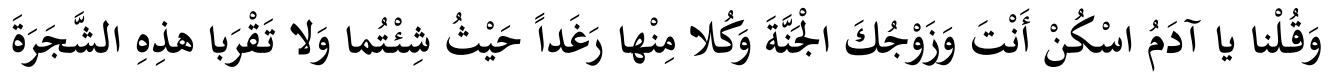 فَتَكُونا مِنَ الظُاَلِمِينَ}

Artinya:

Dan Kami berfirman: "Hai Adam, diamilah oleh kamu dan isterimu surga ini, dan makanlah makanan-makanannya yang banyak lagi baik dimana saja yang kamu sukai, dan janganlah kamu dekati pohon iniyang menyebabkan kamu termasuk orang-orang yang zalim.

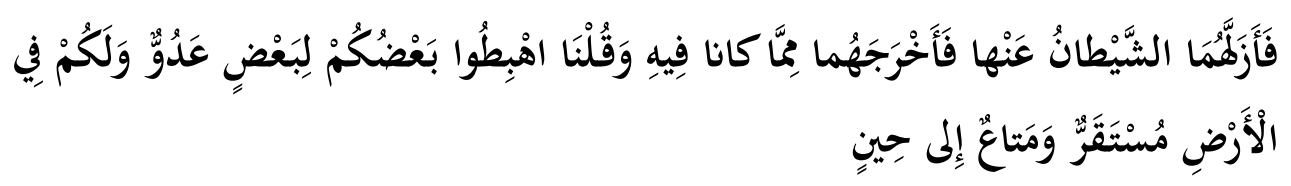

Artinya:

Lalu keduanya digelincirkan oleh syaitan dari surga itu dan dikeluarkan dari keadaan semula dan Kami berfirman: "Turunlab kamu! sebagian kamu menjadi musub bagi yang lain, dan bagi kamu ada tempat kediaman di bumi, dan kesenangan hidup sampai waktu yang ditentukan. 
Namun aturan itu dilanggar mereka yang bermula dari bujukan Hawa, apa yang dilakukan Hawa kepada nabi Adam dalam mengajak memakan buah merupakan sebuah pengkhianatan pertama. Hawa menerima ajakan Iblis sebelumnya Adam menolak rayuan itu, kemudian ia pun terbujuk, terjatuhlah ia pada tindak maksiat. Ini karena adanya sikap khianat perempuan, yakni istrinya Hawa. Pengkhianatan yang dilakukan Hawa kepada suaminya Adam berupa godaannya untuk memakan buah pohon, dan tidak mempunyai pengertian selain itu (Al-Imam Ibnu Katsir, Tafsir alQuran al-`Azhim, 1993).

Buah pohon yang dilarang oleh Allah SWT dalam konteks bahasan terdapat perbedaan ulama dalam identitasnya; ada yang berpendapat bahwa buah itu adalah gandum, ada yang mengatakan buah itu adalah buah tin, dikatakan buah itu kafur atau karam, ada yang menyebutnya buah ilmu sebab ilmu dapat mengetahui segala hal, dan nama yang mashur adalah buah khuldi (Ibnu Mulqan Sirajuddin Abu Hafash al-Syafi i al-Mishri, 2008).

Perbuatan pasangan hidup Nabi Adam yang memperdaya suami sampai mengikuti keinginannya dan mendapat murka Allah dikeluarkan dari surga; merupakan sebuah statemen kecaman dalam konteks لَوَلَا حَوَّاء (seandainya bukan karena Hawa) dalam makna littaubikh (pernyataan buruk). Statemen ini berlanjut pada tataran bahwa perbuatan itu diidentikkan dengan sebuah pengkhianatan istri terhadap suami dan kemudian perbuatan itu dijadikan sebagai sebab; kenapa kaum perempuan mengkhianati suami mereka sepanjang kehidupan manusia dipermukaan bumi. Kesalahan Hawa dijadikan sebuah landasan argumentasi bahwa para istri dari dulu sampai kini mewariskan sifat khianat atas suami dari ibunda pertama manusia. Konotasi ini yang dianggap sebagai tabiat yang melekat pada diri setiap perempuan; jika hadis itu dipahami secara terkstual sehingga dimuncul kepermukaan term misogini. Namun jika dipahami secara kontekstual bahwa perbuatan Hawa itu bukanlah dosa dan tabiat turun temurun yang diwarisi setiap kaum perempuan, tapi hanya sebatas perumpamaan bukan misogini.

\section{Metode Penelitian}

Jenis penelitian yang digunakan adalah penelitian studi kasus. Dalam proses pengumpulan data, penulis melakukan wawancara dan analisa terhadap data dokumentasi. Penulis juga menggunakan pendekatan interpretasi, yakni menyelami 
karya-karya ulama-ulama terdahulu guna menangkap nuansa makna dan pengertian yang dimaksud sehingga tercapai suatu pemahaman yang benar.

\section{HASIL PENELITIAN DAN PEMBAHASAN}

\section{Perspektif Hadis Misogini Atas Pengkhianatan Istri}

Istilah misogini (Echols, jhon dan Hassan Shadily , 1986) terhadap beberapa hadits Nabawi menimbulkan perdebatan yang sangat panjang, tapi penulis menggunakan term untuk memberi dorongan membuka wawasan dan memperlihatkan wajah Islam yang sesungguhnya. Karena fungsi Rasulullah SAW diutus Allah adalah tidak lain mengangkat harkat dan martabat manusia termasuk kaum perempuan. Konstruksi term misogini selalu dikaitkan dengan ketidakadilan gender yang ditimpakan atas kaum perempuan. Di antara fenomena ketidakadilan gender yang diisukan, yaitu (Maulana, 2013); Pertama, marginalisasi perempuan baik di rumah tangga, di tempat kerja, maupun di dalam bidang kehidupan bermasyarakat lainnya. Proses marginalisasi ini berakibat pada pemiskinan ekonomi perempuan; Kedua, subordinasi terhadap perempuan karena adanya anggapan bahwa perempuan itu irrasional, emosional, maka ia tidak bisa memimpin dan oleh karena itu harus ditempatkan pada posisi yang tidak penting; Ketiga, stereotype yang merugikan kaum perempuan, misalnya asumsi bahwa mereka suka dandan dan itu untuk menarik perhatian lawan jenis sehingga menimbulkan kekerasan seksual; Keempat, berbagai bentuk kekerasan menimpa perempuan baik fisik maupun psikologis karena adanya anggapan bahwa perempuan itu lemah; dan Kelima, pembagian kerja secara seksual yang merugikan kaum perempuan, misalnya perempuan hanya cocok dengan pekerjaan domestik, oleh sebab itu tidak pantas melakukan pekerjaan publik seperti laki-laki. Akibatnya perempuan terkurung dalam ruang dan wawasan yang sempit.

Islam memandang perempuan sebagai sosok yang indah, anggun dan berwibawa. Ia laksana mutiara yang sangat berharga. Tidak sembarangan orang boleh melihat, memegang dan memilikinya. Perempuan diposisikan sebagai figur yang terjaga, suci dan terhormat. Untuk itu dalam hal pakaian fisik, Islam mensyariatkan sebuah pakaian khusus yang mampu menjaga kehormatannya, bukan pakaian yang justru menghinakan dan merendahkan martabatnya. Islam juga menuntunkan model pergaulan yang anggun dan terjaga, yang dapat memelihara kesuciannya.

Islam menempatkan perempuan di tempat yg sesuai dan terhormat, mereka bukan makhluk kelas kedua sebagaimana diasumsikan oleh segelintir orang. Kedudukan kaum 
perempuan pada konstruksi kemanusia nampak dalam pengakuan Islam akan haknya sebagai manusia yang sama dengan kaum laki-laki, pada tataram sosial diberikan kepada kaum perempuan untuk beraktifitas yang sesuai dengan kodratnya, sedangkan pada posisi hukum Islam; Islam menyamakan antara kaum laki-laki dan perempuan dihadapan hukum dan pelaksanaannya.

Konotasi posisi kaum perempuan saat menjadi istri dengan fenomena pengkhianatan dalam institusi keluarga adalah amanah yang berkaitan dengan tugas dan fungsi suami istri. Menjaga amanah dan aplikasinya tidak semudah yang dibayangkan, karena seiring perjalanan masa akan menghadapi berbagai problem. Konstruksi misogini

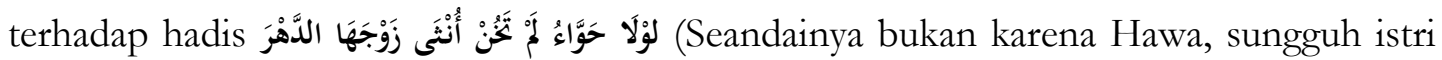
tidak akan pernah mengkhianati suami selamanya), bertolak belakang dengan realita bahwa Islam menempatkan kaum perempuan pada tempat yang mulia tidak seperti dituduhkan, bahwa Islam tidak menempatkan perempuan sebagai unsur subordinat dalam tatanan kehidupan bermasyarakat. Kedudukan mulia kaum perempuan itu ditegaskan dalam banyak hadis, di antaranya:

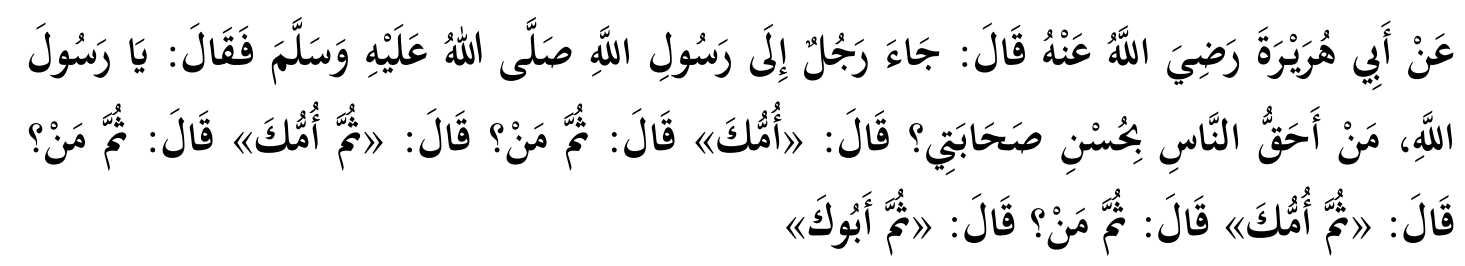

Artinya:

Dari Abu Hurairah RA berkata babwa seorang laki-laki telah datang kepada Nabi Rasulullah $S A W$, lalu bertanya; "Siapa orang yang paling berbak mendapatkan perlakuan baik persahabatanku?", Nabi menjawab: "Ibumu". Laki-laki itu bertanya lagi: "Kemudian siapa lagi?". Nabi menjawab lagi: "Ibumu". Laki-laki itu bertanya lagi: "Kemudian siapa lagi?", Nabi menjawab: "Ibumu". Laki-laki itu bertanya lagi: "Siapa lagi?". Nabi menjawab: "Ayahmu".

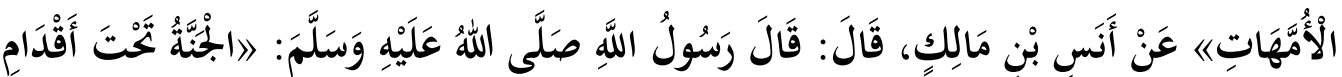

Artinya:

Dari Anas ibn Malik berkata: Rasulullah SAW bersabda: "Surga itu dibawah telapak kaki ibu".

Implementasi kedudukan perempuan sebagai pendamping laki-laki yang bernaung dalam satu institusi rumah tangga berdasarkan pada perbedaan kodrati, dimana peran domestik istri yang merupakan kesejatian kodrat perempuan seperti; sebagai pendidik pertama dan utama bagi anak-anak, hamil, melahirkan, menyusui dan fungsi lain dalam keluarga tidak mungkin digantikan oleh laki-laki. Di sisi lain, terdapat peran-peran yang 
non kodrati dalam kehidupan bermasyarakat antara suami istri harus memikul tanggung jawab bersama dan dilaksanakan dengan saling mendukung satu dan lainnya.

Fenomena suami istri pertama "Nabi Adam dan Hawa" berbeda dengan realitas sekarang dimana institusi rumah tangga terbentuk dari unsur-unsur; (Husein Syahatah, 1998). Adanya suasana yang dapat mengumpulkan anggota keluarga, 2. Adanya individuindividu yang dapat membentuk keluarga, misalnya orang, anak dan sebagainya, 3. Adanya hubungan kekeluargaan yang terjalin antara para anggota keluarga, 4. Adanya penggunaan norma-norma dan nilai-nilai dalam segala masalah keluarga, 5. Bertujuan menciptakan hidup sejahtera di dunia dan hidup bahagia dengan memperoleh ridha Allah di akhirat.

Oleh karena itu, institusi keluarga Nabi Adam dan Hawa belum sampai pada tahap diatas, sebab mereka secara domestik dalam surga dan sifatnya hanya berdua, belum ada orang lain selain mereka. Hubungan pengkhianatan itu tidak sama dengan apa yang terjadi zaman sekarang yang dilakukan oleh istri pada suaminya. Dapat kita lihat teori konstruksi Peter L. Berger yang menyatakan bahwa realitas kehidupan sehari-hari memiliki dimensi subjektif dan objektif. Manusia merupakan instrumen dalam menciptakan realitas sosial yang objektif melalui proses eksternalisasi, sebagaimana ia mempengaruhinya melalui proses internalisasi (yang mencerminkan realitas subjektif). Masyarakat merupakan produk manusia dan manusia merupakan produk masyarakat. Baik manusia dan masyarakat saling berdialektika diantara keduanya. Proses dialektika ini terjadi melalui proses eksternalisasi, objektifikasi, dan internalisasi (Sri Sadewo, 2013).

Teori ini menjelaskan bahwa Nabi Adam dengan Hawa dalam konteks belum memiliki dimensi subjektif dan objektif dibandingkan dengan kehidupan manusia seharihari yang proses internalisasi, eksternalisasi dan objektifitas berjalan sesuai dengan perkembangan budaya dan peradaban. Bila hadis ini dipahami dengan salah, maka akan menimbul sebuah kesimpulan bahwa kaum laki-laki adalah makhluk pertama (lebih dulu ada), sedangkan perempuan adalah makhluk yang kedua dan mempunyai kedudukan dibawah kaum laki-laki. Begitu juga perempuan dipandang sebagai makhluk pertama yang melakukan dosa dengan memakan buah yang dilarang, sehingga itu dianggap sebagai pengkhianatan awal manusia.

Islam dalam menempatkan kaum perempuan menjadi mitra setara bagi jenis kaum laki-laki. Kedudukan laki-laki adalah pelindung bagi perempuan, karena secara fisik dan mental kaum laki-laki memiliki kelebihan kekuatan badan, kesehatan fikiran, keluasaan 
penalaran, kemampuan ekonomi, kecerdasan pikiran, ketabahan, kesigapan dan kelebihan anugerah. Perempuan di tuntut menjadi perempuan yang shaleh, yang mampu menjaga diri, memelihara kehormatan dan kepatuhan kepada Allah, dan memelihara kesucian faraj dibelakang pasangannya, karena Allah telah memuliakan mereka dengan faraj itu. Islam menempatkan perempuan pada derajat mulia (alQaradhawi).

Dalam posisi ini berdasarkan kodratnya, kaum perempuan memiliki peran ganda, sebagai penyejuk hati dan pendidik utama. Kondisi ini menyebabkan surga terhampar dibawah telapak kaki ibu. Di dalam naungan konsep Islam, para perempuan memiliki kepribadian sempurna, pergaulan ma'ruf dan ihsan, kasih sayang dan cinta, kelembutan dan perlindungan, kehormatan dalam perpaduan hak dan kewajiban.

Dalam teori fungsionalisme tentang masalah gender menyoroti bagaimana terjadinya persoalan gender itu mengarah kepada pemikiran bagaimana gender dipermasalahkan. Teori ini memandang bahwa masyarakat merupakan suatu sistem yang terdiri dari bagian-bagian yang saling berkaitan. Dalam kaitannya dengan masalah kesetaraan gender yang sedang disuarakan dapat diartikan bahwa dalam struktur masyarakat telah terjadi suatu kesalahan fungsi atau penyimpangan struktur kehidupan masyarakat yang telah terjadi suatu kesalahan, sehingga terjadi gejolak. Gejolak itu adalah suatu gejala adanya kesalahan fungsi atau struktur kehidupan. Teori ini memandang bahwa laki-laki dan perempuan merupakan bagian dari struktur nilai dalam kehidupan masyarakat (Arsini, 2014).

Sesunguhnya yang diperlukan adalah pemahaman dan pengamalan bulat tentang peran perempuan sebagai mitra, yang saling terkait, saling membutuhkan, dan terjauh dari eksploatasi. Konsep pemahaman azwaajan itu mengandung makna pasangan dengan posisi kesetaraan. Dapat dipahami sebenarnya pengunaan kata pasangan (azwajan) apabila dikaitkan dengan pemahaman bahwa tidak punya arti sesuatu kalau pasangannya tidak ada dan tidak jelas eksistensi sesuatu kalau tidak ada yang setara di sampingnya. "Pasangan", mungkin tidak ada kata yang lebih tepat dari azwajan itu.

Di institusi keluarga, kaum perempuan dalam Islam berbeda dengan apa yang dipahami oleh dunia barat. Dimana ikutan bagi umat dimulai dari rumah tangga. Masyarakat yang baik lahir dari Ibu yang baik. Dalam hubungan sosial dapat dirasakan bahwa kaum Ibu pemelihara rumah tangga, dan perekat silaturrahim. 
Pengkhianatan yang dikatakan oleh Rasulullah SAW dalam hadis tersebut mempunyai maksud yang harus diaplikasikan suami dalam institusi keluarga dengan menentramkan hati para suami agar senantiasa bersabar dan selalu menasihati istrinya dengan kebaikan, karena tabiat yang melekat pada perempuan sama seperti ibu mereka. Namun demikian, tidak boleh beralasan dengan hadis ini untuk melakukan suatu dosa. Sebagaimana juga tidak boleh beralasan dengan takdir untuk suatu dosa. Maka pemahaman atas khianat itu dilandaskan pada makna majazinya, bukan hakiki.

Makna majazi dari hadis asal mula pengkhianatan istri terhadap suami dengan mengacu pada bahwa tidak ada namanya dosa turun temurun;

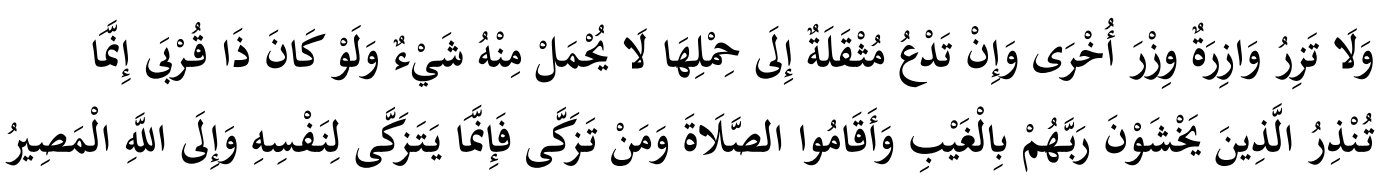

Artinya:

Dan orangyang berdosa tidak akan memikul dosa orang lain. Dan jika seseorang yang berat dosanya memanggil (orang lain) untuk memikul dosanya itu tiadalah akan dipikulkan untuknya sedikitpun meskipun (yang dipanggilnya itu) kaum kerabatnya. Sesunggubnya yang dapat kamu beri peringatan hanya orang-orang yang takut kepada azab Tubannya (sekalipun) mereka tidak melibatNya dan mereka mendirikan sembabyang. Dan barangsiapa yang mensucikan dirinya, sesunggubnya ia mensucikan diri untuk kebaikan dirinya sendiri. Dan kepada Allablab kembali(mu).

Prinsif dasar لَا تَزْرُ وَازِرَةُ وزْزَ أُخْرَى (orang yang berdosa tidak akan memikul dosa orang lain), menetapkan tentang kenyataan adanya pengkhianatan istri terhadap suaminya bukan berkaitan dengan apa yang dilakukan ibunda Hawa dan juga bukan warisan tabiat yang diwariskan Hawa kepada anak cucunya. Islam meletakkan bahwa tidak ada dosa turunan dan tidak ada warisan kesalahan.

Perspektif hadis misogini terhadap Hawa dengan realitas pengkhianatan dalam institusi keluarga anak cucunya menjadi tidak esensi dengan mengacu pada hak dan kewajiban yang proporsional antara perempuan dan laki-laki. Implementasi dari sifat proporsional ini menempatkan bahwa ada kelebihan yang dimiliki suami dan ada kelebihan yang dimiliki istri.

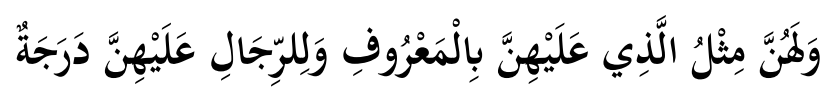

Artinya:

Dan para perempuan mempunyai hak yang seimbang dengan kewajibannya menurut cara yang ma'ruf. Akan tetapi para suami, mempunyai satu tingkatan kelebihan daripada isterinya. 
Membingkai pemahaman terhadap perbuatan Hawa yang menyebabkan suami istri dikeluarkan dari surga pada rekonstruksi hubungan ikatan batin antara suami dan istri. Ikatan batin ini merupakan sebuah paradigma yang menyatakan bahwa istri tidak dapat disalahkan 100 persen dan begitu juga suami tidak dapat disalahkan 100 persen. Hal itu dapat mengacu pada sabda Rasulullah SAW bahwa istri diibaratkan sebagai tawanan di sisi suami.

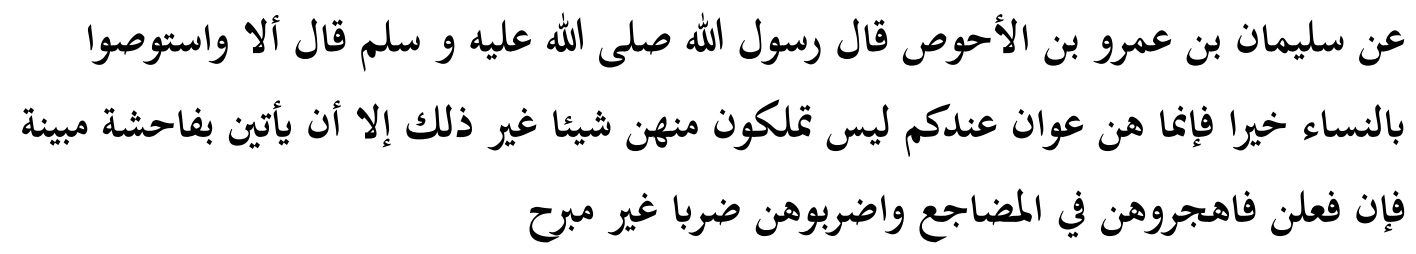

Artinya:

Dari Sulaiman ibn 'Amru ibn al-Ahwash berkata: Rasulullah SAW bersabda: "Berilah wasiat kepada istri dengan cara yang baik, sebab mereka itu (ibarat) tawanan di sisi kalian. Kalian tidak berkuasa atas mereka sedikit pun selain itu (wasiat di atas kebaikan), kecuali jika mereka melakukan perbuatan keji secara terang-terangan. Jika mereka melakukannya, maka tinggalkanlah mereka di tempat tidur dan pukullah mereka dengan pukulan yang tidak menyakiti."

Kalimat yang fundamental dalam hadis di atas adalah هن عوان عندكم (mereka itu adalah tawanan di sisi kalian/suami), pemahaman dari kalimat ini bahwa suami adalah sosok sentral yang mempunyai otoritas atas istrinya, sebagaimana terdapat dalam kitab Tubfah

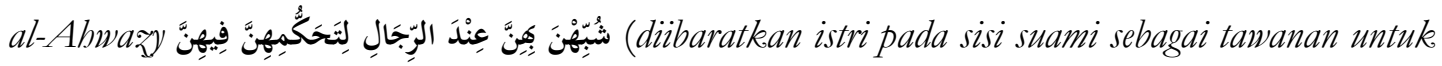
mengokohkan kekuasaan suami pada istri) dan كُلُُ مَنْ ذُلَّ وَاسْتَكَانَ وَخَضَعْ (semua kerendahan, ketenangan dan ketundukan istri) (Muhammad Abdurrahman al-Mubarakfury). Dalam syarh kitab Riyadusshalibin: شبه رسول الله صلى الله عليه وسلم المرأة في دخولها تحت حكم الزوج بالأسير (Rasulullah SAW membuat penyerupaan istri dengan tawanan suami untuk memasukkannya dibawah wewenang suami) (Muhammad al-Shaleh al-'Utsaimin). Implementasi tawanan suami yaitu sang istri bukan untuk merendahkan kaum perempuan, tapi untuk membentuk dan membina keluarga yang terarah sakinah mawaddah wa rahmah.

Oleh karena itu, kedudukan istri dihadapan suami adalah surganya dan nerakanya, dan begitu juga sebaliknya suami dihadapan istrinya adalah surganya dan nerakanya.

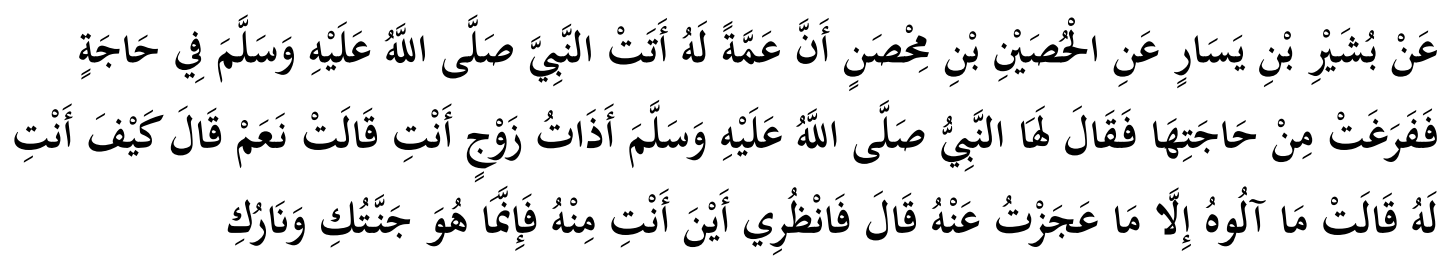


Artinya:

Dari Busyair ibn Yasar dari al-Hushain ibn Mihshan bahwa bibinya datang kepada Nabi SAW dalam suatu hajat, maka tatkala selesai dari hajatnya, Rasulullah SAW bertanya kepadanya: "Apakah engkau telah bersuami?" Ia menjawab, "Sudah." Beliau bertanya lagi, "Bagaimana sikapmu kepada suamimu?" Ia menjawab, "Aku tidak pernah mengurangi (bak)nya kecuali yang aku tidak mampu mengerjakannya." Maka Rasulullah $S A W$ bersabda kepadanya, "Perbatikanlah, kedudukanmu di sisinya, karena sesunggubnya dia (suamimu itu) adalah Surgamu dan Nerakamu."

Kontekstualisasi asal mula pengkhianatan istri dengan mengacu atas perbuatan Hawa terhadap Nabi Adam; tidak mendasar dan tidak relevan dipahami secara tekstual. Sehingga arah konteksnya sebatas ungkapan kiasan dan salah satu yang dapat membingkainya adalah suami diibaratkan surga dan nerakanya istri, begitu juga sebaliknya istri adalah surga dan nerakanya suami. Dalam tinjauan psikologis terdapat dua tipe kepribadian; introvert dan ekstrovert. Tipe kepribadian introvert berupa tidak banyak bicara, mawas diri, memiliki rencana sebelum melakukan sesuatu, tidak percaya dengan faktor kebetulan, memikirkan masalah kehidupan sehari-hari secara serius, menyukai keteraturan dalam hidup mereka, jarang berperilaku agresif, tidak mudah hilang kesabaran, dan menempatkan standar etis yang tinggi dalam hidup mereka. Sedangkan tipe ekstrovert berupa tidak terlalu memusingkan suatu masalah, cenderung agresif, mudah kehilangan kesabaran, perasaannya kurang dapat terkontrol dengan baik, dan kurang dapat dipercaya (Widyastuti, 2015). Kedua tipe kepribadian ini dalam karakteristik suami istri dikiaskan pada surga dan neraka, bagaimana mereka mensikapi karakter masing-masing. Sebab dalam realitasnya, bisa saja suami bertipe introvert dan istri ekstrovert atau sebaliknya, bisa juga suami istri sama tipe kepribadian.

Kasus Nabi Adam dan Hawa secara kepribadian belum dapat dianalisis tipe mereka masing-masing; apakah Adam introvert dan Hawa ekstrovert atau sebaliknya, boleh juga tipe mereka sama, namun konteks pengkhianatan istri jauh berbeda dalam perkembangan dunia peradaban mulai masa Rasulullah SAW sampai sekarang. Mendudukkan Hawa sebagai simbol misogini sangatlah tidak tepat dalam karakteristik bentuk-bentuk pengkhianatan kontemporer yang dilatarbelakangi berbagai hal.

Cermin pernikahan Nabi Adam Dan Hawa adalah suatu peristiwa hidup yang tunggal, sebab mereka permulaan manusia dengan dimensi asal mula produk manusia adalah masyarakat yang terdiri dari suami dan istri, sedangkan produk masyarakat adalah manusia itu sendiri. Perkembangan produk tersebut membuat pernikahan anak cucu Adam Hawa tidak bersifat tunggal lagi tapi berproses pada tataran di mana pasangan 
suami istri mecoba untuk mencapai keseimbangan antara ketergantungan dan otonomi sebagaimana mereka bernegosiasi terhadap masalah kontrol, kekuasaan dan otoritas. Dimensi karakteristik suami istri berpautan dengan institusi keluarga yang mereka bangun di atas pondasi pernikahan.

Institusi keluarga dalam Islam memiliki kepribadian dan keistimewaan sendiri yang berbeda dengan institusi keluarga orang-orang barat atau timur, sebab institusi keluarga Islam itu mengandung nilai-nilai yang berasal dari al-Quran dan Sunnah. Nilai-nilai ini dapat menjauhkan suami istri saling khianat mengkhianati dan realitas nilai-nilai melekat pada institusi keluarga Islam, di antaranya (Syahatah);

1. Keimanan anggota institusi keluarga bahwa hidup mereka hanyalah untuk Allah dan itu adalah tujuan hidup mereka

2. Keyakinan bahwa kehidupan di dunia ini hanya sementara dan yang kekal lagi abadi adalah kehidupan akhirat

3. Kepercayaan para anggota institusi keluarga bahwa Allah akan mengumpulkan orangorang mukmin dari mereka dan lainnya di surga

4. Akhlak mulia dapat mewujudkan ketentraman, kasih sayang dan cinta

Institusi keluarga Islam menjadi tempat yang tenang untuk berteduh, penuh kesabaran dan kerelaan.

\section{E. SIMPULAN}

Hadis tentang asal mula pengkhianatan istri terhadap suami yang digambarkan pada kisah Nabi Adam dan istrinya yang memperdaya memakan buah yang dilarang sehingga mereka dikeluarkan dari surga. Secara tekstual bersifat perumpamaan yang paradigma ungkapannya majazi dan tidak dapat dipahami secara teks. Konteks pengkhianatan Hawa terhadap Nabi Adam bukan konotasinya menurunkan atau mewariskan dosa sehingga kaum perempuan di cap sebagai pendosa dari ibunda manusia pertama. Implementasi yang diinginkan bahwa hadis itu sebatas kiasan dan hubungan suami istri dalam instutusi keluarga persahabatan yang masing-masing mempunyai kelebihan dan kekurangan. Bila terjadi keretakan dalam institusi keluarga dikembalikan bahwa istri adalah tawanan suami dan kehidupan mereka di dunia berkorelasi dengan akhirat, yakni suami adalah surga dan nerakanya istri serta sebaliknya istri adalah surga dan nerakanya suami. 


\section{DAFTAR REFERENSI}

Abu Daud Sulaiman ibn al-As`a ibn Ishaq, Sunan Abu Daud, hadis no. 1905 (Bairut: alMaktabah al-`Ashriyah, tt)

Alfia Nengse dan F.X Sri Sadewo, Konstruksi Istri tentang Peran Suami (Studi Istri Yang Memiliki Penghasilan Lebih Besar Dibanding Suami), dalam Jurnal: Paradigma, Volume 01 Nomor 03 Tahun 2013

A.J. Wensinck, al-Mu jam al-Mufahras Li alfaz al-Hadis al-Nabawi, Percetakan Breel, London, 1943.

Abu al-Fadhl Ahmad ibn Ali ibn Muhammad ibn Ahmad ibn Hajar al-Asqalani, Fath alBary, Dar al-Fikt, Bairut.

Arsini, Peran Ganda Perempuan Pada Keluarga Masyarakat Agraris: Kasus 10 Istri Buruh Tani Di Desa Putat Purwodadi Grobogan, dalam Jurnal $S A W W A$, Volume 10, Nomor 1, Oktober 2014.

Abu al-`Abbas ibn Ahmad ibn Ibrahim, Al-Mufham Lima Asykala Min Talkhish kitab Muslim, Dar al-Fikr, Bairut.

Abu Zakaria Yahya ibn Syarf al-Nawawi, al-Minhaj Syarah Shabih Muslim, Dar Ihya al-Turats al-Arabi, Bairut, 1392.

Abu al-Thayib Muhammad Shadiq Khan ibn Hasan, Fathul Bayan Fi Maqashidul Quran, alMaktabah al-Ashriyah, Bairut, 1992.

Husnu al-Uswah Bima Tsabata Minallah Wa Rasulib Fi al-Niswah, Muassasah alRisalah, Bairut, 1981.

Abu Syuqqah, Tahrir al-Mar'ah fi 'Ashr al-Risalah, Dar al-Qalam, Kuwait, 1410 H.

Imanuddin Abu al-Fida Ismail ibn Katsir al-Quraisy, Tafsir al-Quran al-Azbim, Muassasah al-Kutub al-Tsaqafiyah, Bairut, 1993.

Abdur Rahman Umirah, Rijal wa Nisa`anzala Allah Fibim Quranan, Dar al-Haram Litturuts, Kairo, 2006.

Dirjen Bimas Islam dan Penyelenggaran Haji, Modul Materi Pelatihan Korp Penasehat Perkawinan Dan Keluarga Sakinah, Departemen Agama RI, Jakarta, 2004.

Echols, jhon dan Hassan Shadily, Kamus Inggris-Indonesia, Gramedia, Jakarta, 1986.

Fatimah Mernissi, Women and Islam: An Historical and Theological Enquiry, Oxford, USA, 1991.

Hanim Ilyas, Kontekstualisasi Hadis dalam Studi Agama, dalam bunga rampai Wacana Studi Hadis Kontemporer, PT. Tiara Wacana, Yogjakarta.

Husein Syahatah, Ekonomi Rumah Tangga Muslim, Gema insani press, Jakarta, 1998.

Ismail al-Haqy ibn Mushtafa al-Istanbuly, Ruh al-Bayan, Dar al-Fikr, Bairut. 
Ibrahim Mushthafa, Al-Mu `jam al-Wasith, Dar al-Da`wah, Bairut.

Ibnu Mulqan Sirajuddin Abu Hafash al-Syafi i al-Mishri, al-Taudhih Lisyarh al-Jami al-Shabih, Dar al-Nawadir, Damaskus, 2008.

Maulana, Melacak Akar Bias Gender Dalam Studi Islam, dalam Jurnal Marwah, Vol. XV No. 2 Desember Th. 2016.

Muhammad Abdurrahman al-Mubarakfury, Tubfah al-Ahwasy Bisyarh Jami al-Tirmiæi, Dar alKutub al-Ilmiyah, Bairut.

Muhammad 'Athiyah al-Ibrasyi, Makanah al-Mar'ah Fi al-Islam, Maktabah al-Usrah, Kairo, 2003.

Muhammad ibn Ya`qub al-Fairuzabadi, al-Qamus al-Mubith, Dar al-Fikr, Bairut.

Muhammad ibn Muhammad ibn Abdur Razaq al-Husainy, Taj al-Arus Min Jawahir alQamus, Dar al-Hidayah, Bairut.

Muhammad ibn Makram ibn Manzhur, Lisan al-Arab, Dar Shadir, Bairut.

Muslim ibn al-Hujjaj Abu al-Hasan al-Qusairy al-Nisabury, al-Musnad al-Shahih alMukhtashar Binaqli al-Adli an al-Adli An Rasulillah saw, Dar al-Ihya al-Turast alArabi, Bairut.

Muhammad ibn Hibban ibn Ahmad ibn Hibban ibn Mu`az, al-Ihsan Fi taqrib Shabih Ibnu Hibban, Muassasah Risalah, Bairut, 1988.

Muhammad ibn Ismail Abu Abdullah al-Bukhari, al-Jami al-Musnad al-Shabih al-Mubtashar Min Umur Rasulullab wa sunanibi wa ayyamibi, Dar Thauq al-Najah, Bairut, 1422.

Muhammad al-Shaleh al-'Utsaimin, Syarb Riyad al-Shalibin, Maktab Salafi, Saudi.

Muhammad Said Ramadhan al-buthi, Fiqh al-Sirah al-Nabawiyah, Dar al-Fikr al-Muasir, Bairut, 1991.

Muhammad Salam Jabir, Hal Hunna Naqishat 'Aqli wa Din, Dar al-Salam, Kairo, 2006.

Mahmud Hamdi Zaqzuq, Haqaiq al-Islam Fi Muwajabah Syububat al-Musyakkikin, Wazarah al-Awqaf, Kairo, 2002.

Mustafa al-siba`i, al-Mar`ah Baina al-Fiqh wa al-Qanun, Dar al-Salam, Kairo, 2003.

Quraish Shihab, Wawasan al-Qur'an, Mizan, Bandung, 1996.

Said Qutub, Fi Zhilal al-Quran, Dar al-Syuruq, Bairut, 1990.

Shalih bin Fauzan bin Abdullah al-Fauzan, Panduan Hukum Wanita Muslimah, Menara Kudus, Jogjakarta, 2002.

Salah Al-Din bin Ahmad Al-Adabi. Oleh Bustamin; Metodologi Kritk Hadis, Raja Grapindo, Jakarta, 2004. 
Teti Devita Sari, Ami Widyastuti, Hubungan Antara Kecerdasan Emosi dengan Kemampuan Manajemen Konflik Pada Istri, dalam Jurnal Psikologi, Volume 11 Nomor 1, Juni 2015.

Partanto, Pius A. dan al-Barry M Dahlan, Kamus Ilmiah Populer, Arkola, Surabaya, 1994.

Wahbah al-Zuhaily, DR, al-fiqh al-Islami wa Adillatuhu, Dar al-Fikr, Damaskus, 1996.

Yusuf al-Qaradhawi, DR,Min hadyi al-Islam: al-fatawa mu asharah, Dar al-salam, Kairo, 1995. DR, Halal Haram Dalam Islam, terjemahan, Era Intermedia, Solo, 2003

Zaitunah Subhan, Tafsir Kebencian; Studi Bias Gender dalam Studi al-Quran, LKiS, Yogyakarta, 1999. 